\title{
ON THE OCCURRENCE OF FISH REMAINS IN FOSSIL AND RECENT MARINE DEPOSITS
}

\author{
BY \\ MARGARETHA BRONGERSMA-SANDERS, D. Sc., \\ Leiden
}

The number of fish remains occurring in fossil marine deposits varies within wide limits. In many deposits they are rather scarce, sometimes even wholly absent, whereas in some deposits they are common or abundant. According to DeEcke (I9I3, p. 90) they are scarce in many mesozoic marls, and they are wanting even completely in the devonian Helderberg and Oriskany beds and in the jurassic Opalinus and Renggeri clays.

The deposits with a great number of fish remains are divided by DeEcke into different groups. (The groups that refer to brack:sh and to supersaline water I shall leave out of consideration). The most important group is represented by certain finegrained sediments that probably were deposited near to the shore; very often these are shales (PAUCA, I933, p. II). Many of these socalled fish shales are bituminous (perm:an Kupferschiefer, triassic fish shales of the eastern Alps and Italy, miocene Monterey shales of California, etc.). Besides iso'ated parts of fish these shales often contain more or less complete specimens.

Another group of fossil deposits with abundant fish remains is according to DeECKe (1913, p. 82) represented by certain sands or calcareous sands, often containing glauconite (oligocene marine molasse of southern Germany, oligocene sands of Stettin, cretaceous greensands of Limhamn near Malmö, etc.). These rather coarse sediments contain almost exclusively isolated parts of fish (the finegrained midd!e part of the lower molasse also contains whole skeletons, WeILER, I932). Otoliths and teeth may be very abundant: the sands of Stettin swarm with otoliths, in the greensands of Limhamn Selach:an teeth are abundant. In some of these deposits scales and bones are common (lower marine molasse).

Furthermore fossil fishes often occur in concretions of postdiluvial age of Canada and Norway (socalled Marlekor concreiions); frequently these conta.n remains of Mallotus vil'osus (Müll.), but also remains of other fishes (SARS, I864). For other deposits containing numerous fish remains see DEECKE (1913; 1927).

To explain the accumulations of fossils in certain deposits many hypotheses have been proposed. As an example I shall give a quotation from a modern Bijdragen tot de Dierkunde, Afl. 28. 
handbook on paleontology (MORET, I940, p. 8): "Les courants sousmarins peuvent également déterminer des accumulations de fossiles, soit par traînage (fausse-brèche du Tithonique alpin), soit en créant des variations de température qui tuent les organismes en masse (zones glauconieuses et phosphatées de l'Albien). Certains gîtes fossilifères sont des champs de batailles et des ossuaires, a.nsi les couches phosphatées à Poissons de l'Afrique du Nord. D'autres sont des cimeiières, les organismes ayant été brutalement détruits par des émanations méphitiques d'origine volcanique (Oiseaux de l'Aquitanien de Sa.nt-Gérand-le-Puy) ou par des sources sous-marines toxiques (Poissons des Kupferschiefer du Permien allemand ou du Tertiaire de Puteaux)."

However ingenious such hypotheses may be, they get a certain degree of probability only, if one finds similar occurrences in recent time. In the first place the question must be answered, if in recent time mass mortality of fishes occurs as a result of submarine springs (as MORET supposes to be the cause of death of the Kupferschiefer fishes), or as a result of volcanism, $\mathrm{H}_{2} \mathrm{~S}$, etc. (as has been supposed by other authors for the fish remains of other deposits). Recently I (Brongersma, 1948) have shown that many cases of mass mortality in recent time have been incorrectly interpreted in literature, many of them being erroneously ascribed to volcanism, $\mathrm{H}_{2} \mathrm{~S}$, injurious submarine springs (1.c., p. 47), etc.; the real cause of these mortalities being noxiousness of phytoplankton (red water). The great importance of the latter cases is that they occur repeatedly in the same place. Probably a very great part of all cases of periodically (or episodically) occurring mass mortalities are caused by red water; for other causes that are well founded see for instance GunTER (I947).

In the second place a reply must be given to the following question: Are there recent sediments containing such a number of fish remains that they look like battlefields, charnel houses or graveyards? If they occur indeed, the nature of the sediments must be studied to enable a comparison with certain fossil deposits. The cause of the accumulation must be searched, and with that the relation between the sediment and the peculiarities of the overlying water and of the organisms living in it. It must be ascertained whether accumulations of fish remains in recent sediments occur in regions where mass mortality occurs repeatedly or elsewhere. In this way it is possible to come near to the real cause of fossil accumulations. Unhappily such data are scarce. Stubbings (1939, p. 36) emphasizes: "Previous authors have concentrated on the description of marine deposits largely from the mineralogical and chemical standpoint. Little attention has been given to the biological remains present in the sediments, except by Murray \& Renard (I89I), or to the relationship between the sediments and the fauna." In Stubings' report on the bottom deposits of the John Murray expedition an important attempt has been made to remedy this omission. For many samples the percentage by weight of the different groups has been given. Moreover, Stubbings calculated the "fre- 
quency"; the latter indicates a relationship between the number of specimens or fragments of the different components. If similar data also were known from other parts of the seas, a rather exact survey could be given of the quantity of fish remains in recent marine sedments.

As the oceans swarm with vast schools of fishes, a large number of their remains might be expected to occur in recent marine sediments. From an examination of bottom samples it is, however, apparent that in most sediments fish remains are strikingly scarce. Otoliths are the only remains that occur in many localities; this applies in a less degree to teeth of Selachians, whereas bones and scales occur on rare occas:ons only. The number of samples of some

\begin{tabular}{|c|c|c|c|c|c|c|}
\hline \multirow{2}{*}{ Expedition } & \multirow{2}{*}{$\begin{array}{l}\text { total number } \\
\text { of samples }\end{array}$} & \multicolumn{4}{|c|}{ number of samples with } & \multirow{2}{*}{ literature } \\
\hline & & otoliths & $\begin{array}{c}\text { Selachian } \\
\text { teeth }\end{array}$ & bones & scales & \\
\hline Challenger.... & 348 & 101 & 65 & 3 & $\mathbf{I}$ & MURRAY \& RENARD, 1891 \\
\hline $\begin{array}{l}\text { Valdivia .... } \\
\text { various expedi- } \\
\text { tions in the } \\
\text { Atlantic.... }\end{array}$ & 119 & 22 & 100 & 3 & & $\begin{array}{l}\text { Murray \& Philippi, } 1908 \\
\text { Murray \& Chumley, } 1924\end{array}$ \\
\hline $\begin{array}{l}\text { John Murray ... } \\
\text { Siboga ..... } \\
\text { Snellius ..... }\end{array}$ & $\begin{array}{c}53 \\
102 \\
\text { over } 300\end{array}$ & $\begin{array}{c}4 I \\
\text { several } \\
22\end{array}$ & 12 & 19 & 9 & $\begin{array}{l}\text { StubBings, } 1939 \\
\text { BögGit.D, } 1916 \\
\text { NeEb, 1943 }\end{array}$ \\
\hline
\end{tabular}

expeditions that conta:n fish otoliths, teeth, etc. is shown in the following table; the list is rather short, as several authors do not mention whether such remains occur in their samples (NEAverson, 1934, etc.).

According to MurRay \& Renard (1891, p. 267) otoliths are tolerably abundant in all the calcareous oozes and are frequently present in Red clays. They are found to a depth of $5485 \mathrm{~m}$ (Murray \& Chumley, 1924). They occur, however, in a few samples only of depths exceeding $4000 \mathrm{~m}$. So they afford a sharp contrast as compared to the distribution of Selachian teeth, for the latter occur particularly in sediments of great depths. Only I 5 of the $33^{2}$ samples with otoliths recorded by MURRAY \& CHUMLEY come from depths exceeding 2000 fathoms, whereas no fewer than 64 of the Ioo samples with teeth derive from such depths. The number of otoliths in a sample is usually not high. In the samples of the Siboga expedition they never occur in great quantity; the highest number was found near the Key islands (BöGGILD, I916, p. I3). In the samples of the Snellius expedition the number of otoliths was very small (NEEB, 1943, p. 245). An unusual number of otoliths seems to occur in deposits from the Gulf of Mexico in depths from 725$2900 \mathrm{~m}$ (Agassiz, I888, p. 28I).

Teeth of Selachians occur in marine sediments of nearly all depths. In most of these sediments they are, however, by no means common. According to MurRay \& RENARD (I89I, p. 267) teeth of fish are rather rare in terrigenous deposits, and tolerably abundant in some pelagic deposits. In certain 
regions of the Central Pacific and other oceans in great depth far removed from land shark's teeth occur in great quantity, of ten together with bones of whales; many of these remains are more or less impregnated with oxides of manganese or iron (MURray, I889; MURray \& Renard, I891 ; Eastman, I903, 1906). Owing to the small rate of deposition it happens that teeth of extinct species of sharks lay on the bottom unburied, and are found commingled with those belonging to the modern fauna. Particularly large hauls of shark's teeth and bones of wha:es were made within socalled barren areas of the southern Pacific; that is to say, areas characterized by a most meagre pelagic fauna (EAstman, r906). Therefore, EAstman supposes that the sharks and whales died by starvation: "The extent of these regions is sometimes such as to constitute veritable deathtraps, comparab!e to deserts on the land, for marine vertebrates that happen to have strayed therein." I shall of fer no opinion as to whether this hypothesis is correct. As the rate of deposition (of other material) is extremely scanty, great accumulations of fish remains may occur in this area, even if the number of fishes sinking to the bottom is small.

DeEcke (I9I3, p. 83) emphasizes that most of the fossil deposits with abuindant shark's teeth are deposited in rather shallow water (greensands of Limhamn, etc.); the accumulation of shark's teeth in recent sediments of extreme depths, therefore, cannot be considered as an analogon of such fossil deposits. Except these accumulations at very great depths, Selachian teeth in most recent sedimen's are rare. On the east coast of the United States, in the Gulf of Mexico and in the Caribbean, shark's teeth have been dredged, but rarely (Agassiz, I880, p. I45). Therefore, Agassiz remarks: "Either the sharks of former times were much more numerous, or, as has been suggested by Professor Verill, their remains, as well as those of fishes and other vertebrates, were not immediately devoured by other inhabitants of the sea." However, there always remains a possibility that somewhere in comparatively shallow water recent sediments with abundant Selachian teeth occur. In this respect it is important that nearly all Selachian teeth of the John Murray expedition occurred in samples from comparatively shallow water (II samples came from depths varying from 193 - $1061 \mathrm{~m}$ ) rather near to the shore; it must, however, be admitted that at no station they were very common (STUBBINGS, I939, p. I50).

Bones and scales have a rather great depth range. The greatest depth recorded by the John Murray expedition is $1269 \mathrm{~m}$ for bones and 1061 $\mathrm{m}$ for scales (StUbBING, I939, p. 150), By the Challenger expedition bones are recorded from a depth of 1875 fms., and scales from a depth of $1800 \mathrm{fms}$; so bones and scales may occur at a depth of more than $3000 \mathrm{~m}$. However, bones and scales are lacking nearly altogether in most recent marine sediments. Many authors (Murray \& Renard, I89I ; EAstman, I903, p. I89; BöGGILd, r9I6, p. 3I) expressed their astonishment about the extreme rarity of these remains. MURRay \& Renard (189i, p. 267) remark with regard to the 
Challenger materials: "When we remember the enormous number of fishes that inhabit the ocean the rarity of their rema:ns in nearly all marine deposits is a very striking fact. In only three or four instances were any fish bones, other than otoliths and teeth observed in the deposits brought up in the dredges and the trawls. In 1875 fathoms, of $f$ the coast of Japan, two vertebrae were found, and on other occasions a scapula and a vertebra." Two of these samples were blue mud and the third taken near the Cape of Good Hope green sand; the latter conta:ns otoliths, teeth and bones. Stubbings (I939, p. I50) emphasizes that scales are not recorded from any of the Challenger materials. This is not wholly correct, as they occur at sta. $\mathrm{r}_{5} 8$, but at any rate it is apparent that they are very scarce. The solitary evidence of bones of fishes obtained by the Albatross expedition (I899-1900) in the S E Pacific was a small scapula (EAstman, 1903). Among the materials of the Siboga expedition from one sample only a fish bone has been recorded (BöGGILD, I9I6, p. 3I). Many of the samples of the Challenger and of other expeditions mentioned above have been dredged in deep water far of $f$ the land and, therefore, they prove mainly that bones (and scales) are lacking nearly altogether in oceanic sediments. However, they seem to be also rare in sediments occurring less far off the land. Agassiz (1888, p. I44) mentions: "The scarcity of vertebrate bones is very marked. Mr. Pourtalès" (see Pourtalk̀s, I869) "who seems to have been more fortunate than all others, dredged up a few manatee ribs in the Straits of Florida. Neither the Fish Commission nor the "Blake" has been equally succesful.". VERILL (1884, p. 1054) mentions about the results of a research of the bottom of the Gulf Stream: "Very rarey do we meet with the bones of vertebrates at a distance from the coast. Although these waters swarm with vast schools of fishes, while sharks and a large sea-porpoise or dolphin (Delphinus delphis) occur in large numbers, we have, very rarely indeed, dredged up any of their bones, or, in fact, remains of any other vertebrate animal. In a few instances we have dredged a single sample of a shark's tooth and occasionally the hard otoliths of fishes. It is certain that not only the flesh, but most of the bones, also, of all vertebrates that die in this region are very speedily devoured by the various animals that inhabit the bottom. Echini are very fond of fish-bones, which they rapidly consume." WASMUND ( 1935, p. 50) emphasizes that this does not apply only to regions at a distance from the coast, but also to near shore sediments, referring to samples seen by himself from the North Sea and the Baltic. On my request if fish remains occur in sediments of Danish waters Dr. H. Blegvad kindly informs me: "Bones of fish are found only in very small quantitie in bottom samples in the Danish waters, especially where the bottom material consists partly or exclusively of mud. In no places they form an important part of the bottom material. Otoliths or teeth of fish seem to be even more scarce. Dead fishes may be found now and then in the trawls of the fishermen, especially where an intensive fishery has been carried out, or after severe winters." (see 
Johansen, 1929) "They seem to be destroyed rather quickly by carnivorous invertebrates." Dr. J. VERWEY informs me that vertebrate remains are nearly completely wanting in the samples taken by the Dutch Zoological Station in the North Sea and the Wadden Sea. In samples taken in the former Dutch Zuiderzee, fish bones did not occur either (Mrs. W. S. S. van DER FeenVan Benthem Jutting, in litt.).

From the shallow Java Sea (East Indian Archipelago), in 1918 and thereafter, a great number of bottom samples were taken by the then Department of "Landbouw en Nijverheid" (NEEB, I943, p. 67). These samples were examined by E. C. J. Mohr and J. Th. White. Prof. Mohr informs me as to the occurrence of fish remains : Except for a few fish scales I never found any fish remains; teeth of Selachians occurred on rare occasions only. I never found any skeletons or loose fish bones.

- It must be admitted that the examples of scarcity of fish remains in near shore deposits refer to a small part of the seas only: it is, however, probably safe to say that bones are absent or very scarce not only in oceanic, but also in many littoral sediments. There are, however, certain localities near to the shore, where such rema:ns are common or even abundant. A complete survey of these localities should be very interesting from a paleontological point of view. In the present paper only a few examples will be given.

According to Porsild (1902, p. 219) in the inner parts of the Bay of Disko (Greenland) there are peculiar white spots on the bottom consisting of remains of Mal'otus villosus (Müll.) in all stages of decomposition. PorsILD points to the fact that a mass mortality of this fish occurs annually in this locality. Further he connects the accumulation of Mallotus remains on the bottom of Disko Bay with the above mentioned postglacial Marlekor concretions of Canada and Norway. An examination of bottom samples taken at some distance under the surface, therefore, would be very interesting. With regard to the wide distribution of the fossil concretions it is important that mass mortality of Mallotus also has been recorded from other localities in northern seas. Weigelt (1927, p. I43, see also p. 220) mentions that mortality occurs near Disko and Lodden; the latter probably is an error, as Lodde is the german name for Mallotus. Mass mortality of this fish is, however, recorded from several other localities: New Foundland (in July 1839, JoNEs, 1882; in August I853, Collins, I883, p. 282), Barents Sea (HJORT, I914, p. 208), Alaskan Islands (at Metlakatla in August 1897, Jordan, 1925, p. 349); see further SlegGs (1927, p. 38 and 4I). The cause of death is according to most authors connected with spawning; according to HJORT (in MurRay \& HJORT 1912, p. 208) the mortality in the Barents Sea is accompanied by great changes in the temperature of the sea water.

Secondly fish bones occur in sediments that may be classified as marine gyttja. According to Sjöstedt (1922, p. I7 and p. 23) bones of fish and of other marine vertebrates occur in gyttja of the Öresund and the southern 
Baltic. Sample 68 of the Valdivia (coprolitic mud near the mouth of the Congo containing fish vertebrae and otoliths; MUrray \& Philippi, I908, p. I03) and sample 176 of the John Murray expedition (green coprolitic and Globigerina mud west of Cape Gardafui containing vertebrae, otoliths and shark's teeth) belong to the same group. Furthermore accumulations of fish bones occur in sediments that are a (or are near to a) sapropelium (for the difference between gyttja and sapropelium, see WASmUND, 1930). Such sediments remind of bituminous fish shales. Great accumulations of fish bones occur in the azoic region near Walvis Bay ( $\mathrm{S} W$ Africa) (Brongersma, 1948). A similar accumulation of fish remains together with remains of cephalopods occurs in the sediment of the Bay of Talcahuano (S America) (FALKE, 1939). Both sediments are near to a true sapropelium.

Fish bones also are found in the deep water sediments of the Black Sea. MurRay (I900) found bones and scales of small fishes (probably Syngnathus) in some of the samples collected during the Russian explorations in 1890 and i891; see also Andrussow (1893). Archanguelski (i927, p. 208) mentions that fish remains often occur in the samples collected by the expeditions of J. M. ShokAlski in 1925 and 1926; there occur marvellous preserved specimens. As the sediment is a true sapropelium such a good preservation was to be expected. Well preserved specimens probably also occur in the sapropelium like sediments of the Walvis Bay area and of Talcahuano. Archanguelski (1927, p. 285) and others emphasize that the Black Sea deep water mud shows a great resemblance with the Kupferschiefer; see also Wolanski, I933. The Kupferschiefer fishes belong however, for a very great part to benthonic living species (РомрескJ, I9I4); it does not seem propable that this is the case with the fish remains of the Black Sea.

Finally fish bones and scales are common or even abundant in some of the samples of the John Murray expedition (Stubbings I939), some of which are gyttja or are near to a sapropelium. These remains were common (C), very common (VC) or abundant (A) at a few stations only. These are the following:

\begin{tabular}{l|c|c|c|c}
\hline \hline & station & "frequency" & $\begin{array}{c}\% \text { coarse } \\
\text { material 1) }\end{array}$ & $\%$ deposit 1) \\
\hline Red sea & 206 & C & 6.4 & 0.8 \\
$n$ Vicinity of Bir Ali & 207 & VC & 10.3 & 1.2 \\
" & 33 & C & - & - \\
Vicinity of Cape Gardafui & 188 & VC & 11.9 & 0.4 \\
near Cape El Hadd & 176 & C & 6.2 & 0.4 \\
northern Arabian Sea & 56 & VC & 10.7 & 0.5 \\
& 77 & A & 28.3 & - \\
& 88 & C & 6.3 & 0.1
\end{tabular}

I) The percentage figures are calculated on weights. 
The comparatively high number of samples containing bones and scales is conspicuous (see table on p. 67). Bones have been recorded from the following stations (as the fish remains in part of the samples are unspecified, $\mathrm{r} 3$ of the I9 samples can be mentioned only): somewhat north of Cape Gardafui 28, I76; near Cape El Hadd 56, 57, 77, 79; Gulf of Oman 64, 65, 67, 74, 75: Maldive Archipelago 142b, I60. Scales are recorded from the following stations: Red Sea 207; Gulf of Aden I93; vicinity of Bir Ali 33, near Cape E.I Hadd 55, 56, 57, 77; Gulf of Oman 65, 75 (for the stations in the Maldive Archipelago that are not indicated on the accompanying map (fig. I), see Sewell, 1935). At several of these stations bones (and scales) are, however, rather rare, e.g., at the stations in the Maldive area, where a few fish bones occur in sediments of very shallow water (lagoon mud); neither such remains were common at any of the stations in the Gulf of Oman.

The most interesting area is that near Cape El Hadd. Since Sewell's paper of 1934 this area is well known in oceanographical literature (see ScHotT, 1935, p. 178 , etc.) on account of the fact that $\mathrm{H}_{2} \mathrm{~S}$ occurs in some of the samples (a great quantity at stas. 56 and 77, much less at stas. 57 and 79). It is, however, also very important that fish remains occur in nearly all samples dredged up in this area $(54,55,56,57,58,59,77,79$ and somewhat more offshore at sta. 8I); at some of these stations fish remains are very common (sta. $5^{6}$ ) or even abundant (sta. 77). At stas. 54 and 59 there occur shark's teeth, at sta. $5^{8}$ otoliths, at sta. 55 some scales, at sta. 79 a few fish bones.

At sta. 56 fish bones and scales are very common, otoliths and shark's teeth also are present, but in fewer numbers. At sta. 57 animal remains are rare; the chief components are fish bones, scales and otoliths. At sta. 77 the commonest animal remains are bones and scales of fish; otoliths are not common. It is an interesting fact that fish bones occur in all of the samples containing $\mathrm{H}_{2} \mathrm{~S}$ and that they are very common or abundant at stas. 56 and 77 , containing a great quantity of $\mathrm{H}_{2} \mathrm{~S}$. The depth of these stations is $42 \mathrm{I}$ and $4 \mathrm{II} \mathrm{m}$ respectively. They lay nearly in the centre of the large fish cemetary; the position of the cemetary is about $21^{\circ} 50^{\prime}$ to $22^{\circ} 25^{\prime} \mathrm{N}$ and $59^{\circ} 49^{\prime}$ to $60^{\circ} \mathrm{IO}^{\prime} \mathrm{E}$.

A small amount of $\mathrm{H}_{2} \mathrm{~S}$ occurs at sta. 189 in the vicinity of Bir Ali. Fish remains occur in this sample, but they are rare. Somewhat more of fshore, however, at sta. I 88 ( $13^{\circ} 43^{\prime} 18^{\prime \prime} \mathrm{N} 47^{\circ} 56^{\prime} 54^{\prime \prime} \mathrm{E}$ to $\mathrm{I} 3^{\circ} 46^{\prime} \mathrm{oo}^{\prime \prime} \mathrm{N} 47^{\circ} 50^{\prime}$ $42^{\prime \prime}$ E) fish remains (unhappily they are unspecified) are very common, whereas at the close-by sta. 33 ( $13^{\circ} 4 \mathrm{I}^{\prime} \mathrm{Oo}^{\prime \prime} \mathrm{N} 48^{\circ} \mathrm{I} 7^{\prime} \mathrm{OO}^{\prime \prime} \mathrm{E}$ to $\mathrm{I} 3^{\circ} 40^{\prime} \mathrm{Oo}^{\prime \prime}$ $\left.\mathrm{N} 48^{\circ} 19^{\prime} \mathrm{oO}^{\prime \prime} \mathrm{E}\right)$ fish scales are fairly common. Apparently here is another great fish cemetary.

In the third place fish remains are very common in the Red Sea at sta. 207, that is just north of the "sill". Shark's teeth and scales are recorded from this sample, but further it is unspecified. Fish remains are common at the nearby sta. 206. Finally fish bones (vertebrae and other bones together with otoliths and shark's teeth) are recorded from sta. I76 near Cape Gardafui (C), whereas bones and otoliths also occur at the nearby sta. 28 . 


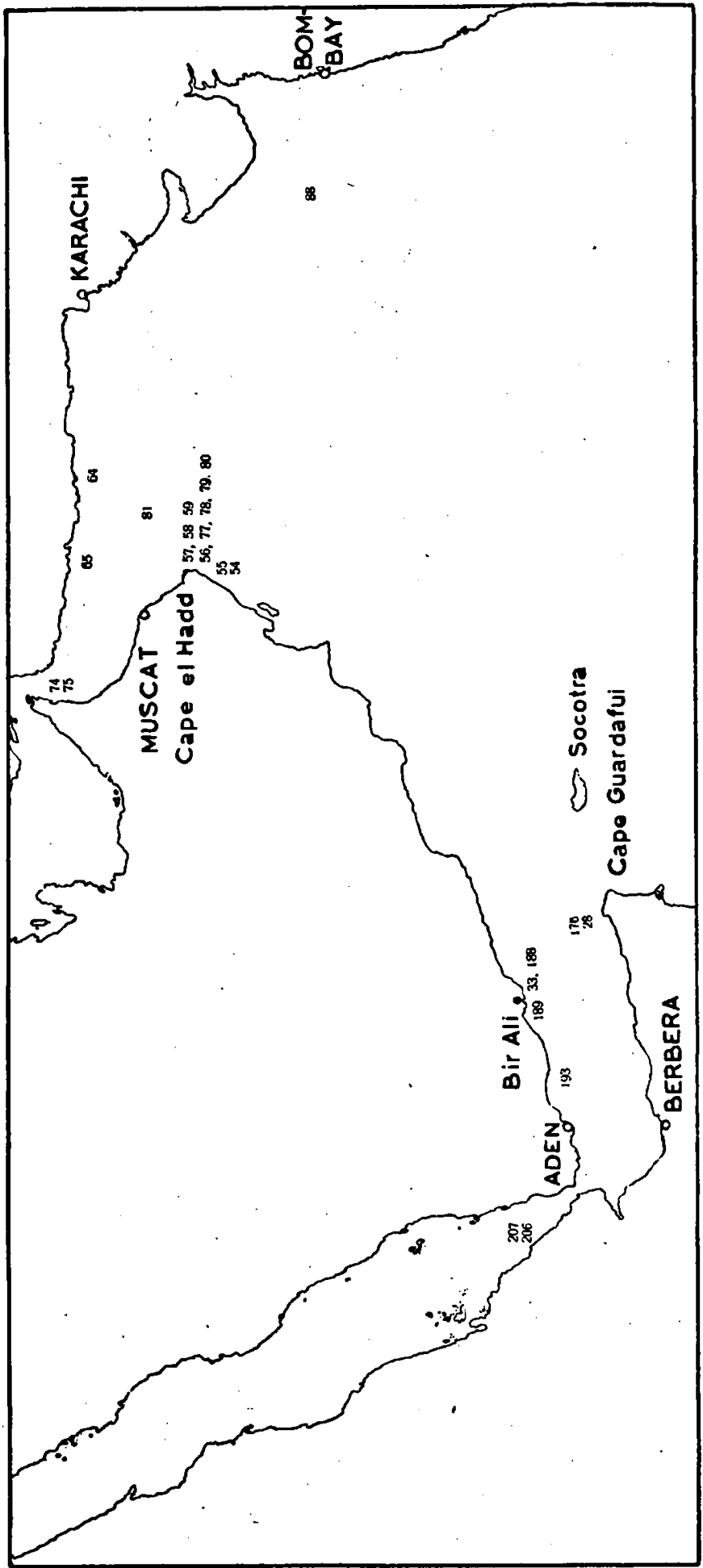

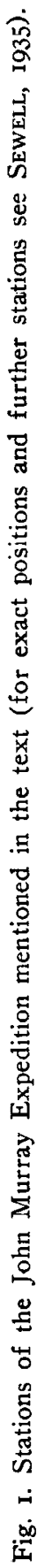


How must these great aocumulations of fish remains be explained? Circumstances will be favourable for the preservation and accumulation of calcareous remains. With regard to the accumulation it is important that the supply with terrigenous debris will be relatively scarce, and that fish life is abundant. It seems, however, doubtful that this is a sufficient explanation for the frequency of bones at some of the stations.

The excessive scarcity of bones in most marine sediments probably cannot be explained by the solvent action of seawater alone, but it will also be due to the fact that dead fishes are eaten by animals inhabiting the sea bottom. Sometimes the entire fish is swallowed; in other cases, however, e.g., when it is pulled to pieces by a crab, the bones are left behind (Dr. J. Verwey in litt.). It must be searched if other invertebrates play an important part in destroying these bones, as has been supposed by VeriLl (see p. 69), or if the solvent action of sea water is the chief agent. Accumulations of fish bones are present on places where mass mortality occurs repeatedly (Disko; azoic region near Walvis Bay; Talcahuano). Great fish mortalities often occur near the Cape of Good Hope (Brongersma, 1948, p. 58) and, therefore, it is not excluded that the above mentioned presence of bones and other remains in green sand near this Cape (Challenger sta. 142) has some connection with these mortalities. Mass mortality also occurs in the Black Sea. JG. (1928) mentions an enormous mortality that occurred near the coasts of the Crimea. It is unknown to me if such mortalities have anything to do with the rather frequent occurrence of fish bones (and whole fishes) in the deep water deposits. It seems likely that they have some connection with the fact that aerobic animals cannot live in the deeper parts of this sea, so that "eaters" are wholly absent.

As accumulations of fish bones in different parts of the sea have been connected with mass mortality (or absence of eaters?), it must be studied whether these also have any connection with the cemeteries near the coasts of Arabia (and with those near Cape Gardafui). Because upwelling occurs in summer time along the coasts of Arabia to Cape El Hadd and along the coast of Africa to Cape Gardafui I (BRongersma, 1948) suppose that mass mortality occurs in several regions along these coasts as a result of red water. Until now only a few reconds of mortality in red water (in less concentration the colour may be yellow) from this region are known to me. They are recorded from the southern part of the Red Sea. Furthermore on one occasion during the John Murray expedition red water occurred off the coast of $S$ Arabia due to enormous numbers of Noctiluca (Dr. R. B. Seymour Sewell, in litt.). A yellow discoloration of the sea has been observed from the air on several occasions between Bir Ali and Mukalla, that is rather near to stas. 188 and 33, where fish remains are common. From the regions near Cape El Hadd and Cape Gardafui unhappily no records are known to me. STUBBINGS (1939, p. II2) supposes that there is a great destruction of life about Cape El Hadd, because highly saline water flowing out of the Persian Gulf 
comes into contact with the bottom. Whether this or red water is the cause of a mass mortality can only be solved by observations in loco.

From the above mentioned it will be obvious that the number of fish remains occurring in recent marine sediments gives a wholly incorrect idea of the number and of the species of fish living in certain areas. Accumulations of Selachian teeth occur in the "barren" areas of the Pacific. On the contrary in sediments of the Gulf Stream, where sharks and other fishes occur in large numbers, a shark's tooth and occasionally some otoliths are the only remains; these sediments will contain little evidence even of the existence of the commonest fishes inhabiting the same waters. Only the accumulations of various kinds of fish remains (bones, teeth, scales, otoliths, probably also more or less complete specimens) that occur in certain areas near coasts will give a fairly good impression of the fish fauna inhabiting these waters. Such accumulations often can be connected with periodically occurring mass mortalities.

I am indebted to the following persons for supplying me with information bearing on the object of this paper: Dr. H. Blegvad (Charlottenlund); Mrs. W. S. S. van der Feen-van Benthem Jutting (Amsterdam); Prof. E. C. J. Mohr (Hilversum); Lieut. Col. R. B. Seymour Sewell (Cambridge); Dr. J. Verwey (Den Helder).

\section{LITERATURE}

Agassnz, A., 1888. Three cruises of the United States coast and geodetic steamer "Blake", vol. I. Bull. Mus. Comp. Zool., vol. XIV, pp. I-XXII, I-220.

Andrussow, N., I893. Einige Resultate der Tiefseeuntersuchungen im Schwarzem Meere. Mitt. Geogr. Ges. Wien, vol. 36 (n.s. 26), pp. 373-:.93.

Archanguelski, A. D., 1927. On the Black Sea sediments and their importance for the study of sedimentary rocks. Bull. Soc. nat. Moscou, n.s., vol. 35, sect. géol. vol. 5, pp. $199-289$.

BöGGILD, O. B., I9I6. Meeresgrundproben der Siboga-Expedition. Siboga Expeditie, vol. 79, monogr. 65, 50 pp.

Brongersma-SANDERS, M., 1948. The importance of upwelling water to vertebrate paleontology and oil geology. Verh. Kon. Ned. Akademie Wet., sect. 2 Nat., vol. XLV, no. $4,112 \mathrm{pp}$.

Collins, J. W., I884. History of the Tile-fish. Rep. U.S. Comm. Fish and Fisheries, vol. I0, (1882), pp. 237-294.

Deecke, W., I9I3. Palaeontologische Betrachtungen. IV. Uber Fische. Neues Jahrb Min. Geol. Pal., II, pp. 69-92.

- 1927 . Uber die Triasfische. Pal. Zeitschr., vol. 8, pp. 184-198.

Eastman, C. R., 1903. Shark's teeth and Cetacean bones. Rep. Sci. Res. Exp. Trop. Pac. Alex. Agassiz, Albatross 1899-1900. Mem. Mus. Comp. Zool., vol. 26, pp. 177-192.

-, 1906. Shark's teeth and Cetacean bones. Rep. Sci. Res. Exp. Trop. Pac. Alex. Agassiz, Albatross 1904-1905. Bull. Mus. Comp. Zool., vol. 50, pp. 75-98.

FALKE, H., 1939. Uber rezente Sedimentbildung in der Bucht von Concepcion. (Mittel Chile). Petroleum, vol. 35, pp. 640-644, 658-662.

Guinter, G., 1947. Catastrophism in the sea and its paleontological significance, with special reference to the Gulf of Mexico. Am. Journ. Sci., vol. 245, pp. 669-676.

JG., 1928. Grosses Fischsterben im Schwarzen Meer. Mitt. Deutsch. Seefisch. Ver., vol. 44, p. 501 . 
Johansen, A. C., 1929. Mortality among porpoises, fish, and the larger crustaceans in the waters around Denmark in severe winters. Rep. Da. Biol. Stat., vol. 35, pp. 63-97.

JoNes, T. R., I882. Notes on the sudden destruction of marine animals. Geol. Mag. London, n.s., vol. IX, pp. 533-540.

Jordan, D. S., 1925. Fishes. 2nd ed., New York \& London, XV + 773 pp.

Moret, L., 1940. Manuel de paléontologie animale. Paris, 675 pp.

Murray, J., I889. On marine deposits in the Indian, Southern, and Antarctic Oceans. Geol. Mag., n.s., III, vol. 6, pp. 514-5I7.

-, I900. On the deposits of the Black Sea. Scott. Geogr. Mag., vol. XVI, pp. 673-702.

Murray, J. \& J. Chumley, 1924. The deep-sea deposits of the Atlantic Ocean. Trans. R. Soc. Edinburgh, vol. 54, pt. I, 252 pp.

Murray, J. \& J. HJort, I912. The depths of the Ocean. London, 821 pp.

Murray, J. \& G. V. LeE, 1909. The depth and marine deposits of the Pacific. Mem. Mus. Comp. Zoöl., vol. 38, pt. I, 169 pp.

Murray, J. \& E. Philippi, 1908. Die Grundproben der ,Deutschen Tiefsee-Expedition". Wiss. Ergebn. Deutsch. Tiefsee Exp. Valdivia, vol. Io, pp. 80-206.

Murray, J. \& A. F. Renard, I89I. Report on the Deep-sea Deposits. Sci. Res. "Challenger" I872-1876, London, $525 \mathrm{pp}$.

Neaverson, E., I934. The sea-floor deposits. Discovery Repts., vol. 9, pp. 295-350.

NeEB, G. A., 1943. The composition and distribution of the samples. Snellius-Exp., vol. 5, Geol. Res. 3, Bottom sampl., sect. 2, pp. 47-268.

Pauca, M., 1933. Die fossile Fauna und Flora aus dem Oligozän von Suslanesti-Muscel in Rumänien. An. Inst. Geol. Rom. (Bukarest), pp. I-99.

PompeckJ, J. F., 19I4- Das Meer des Kupferschiefers. Branca Festschr., Leipzig, pp. 444-494.

Porsild, P., 1902. Bidrag til en skildring af Vegetationen paa Øen Disko tilligemed spredte topografiske og zoologiske Iagttagelser. Medd. om Grønland, vol. 25, pp. 9r, pp. 239.

Pourtalès, L. F. DE, 1869. Contributions to the fauna of the Gulf Stream at great depths (2nd ser.). Bull. Mus. Comp. Zoöl., vol. I, pp. I21-14I.

Sars, M., I864. The fossiliferous nodules in the Post-tertiary clay of Norway. Geol. Mag., vol. I, pp. 158-16r.

Schotт, G., 1935. Geographie des Indischen und Stillen Ozeans. Hamburg, 4I3 pp.

Sewell, R. B. Seymour, 1934. The John Murray expedition to the Arabian Sea. Nature, vol. I33, pp. $86-89,669-672$; vol. I34, pp. 685-688.

- 1935. Introduction and list of stations. Sci. Rept. John Murray Exp. 1933-34, vol. I, no. I, pp. I-4I.

SJöstedT, L. G., 1922. En Orientering över bottenförhållandena I Öresund och södra Östersjön. Lunds Univ. Årrskrift, n.s., sect. 2, vol. I8, no. 5, pp. 1-30.

SLEGGS, G. F., 1933. Observations upon the economic biology of the caplin (Mallotus villosus O. F. Müller). Rep. Newfoundland Fish Res. Comm., vol. I, no. 3, pp. I-66.

Stubbings, H. G., 1939. The marine deposits of the Arabian Sea. An investigation in their distribution and biology. Sci. Rept. John Murray Exp. 1933-34, vol. 3, no. 2, pp. $3 \mathrm{I}-\mathrm{I} 58$.

VerILL, A. E., 1884. Physical characters of the portion of the continental border, beneath the Gulf Stream, explored by the fish hawk, 1880 to 1882. Rep. Comm. Fish and Fisheries, vol. 10, 1882, pp. I045-1057.

Wasmund, E., I930. Bitumen, Sapropel und Gyttja. Geol. Fören, Forhandl. (Stockholm), vol. 52, pp. 315-350.

- 1 1935. Die Bildung von anabituminösem Leichenwachs unter Wasser. In: Erdölmuttersubstanz. Schr. Geb. Brennstoff-Geol., vol. 10, pp. I-70.

WeIgel,T, J., 1927. Rezente Wirbeltierleichen und ihre paläobiologische Bedeutung. Leipzig, XVI + 227 pp.

Weicer, W., 1932. Die Fischfauna der unteren und oberen Meeresmolasse Oberbayerns. Neues Jahrb. Min. Geol. Pal., Abh., Beilage Bd. 68, Abt. B, pp. 305-352.

Wolanski, D., I933. Untersuchungen über die Sedimentationsverhältnisse des Schwarzen Meeres und ihre Anwendung auf das nordkaukasische Erdölgebiet. Geol. Rundschau, vol. 24, pp. 397-410. 